\title{
Revisiting the Technological and Non- Technological Challenges to Municipal E-Government in Spain
}

\author{
Claver-Cortes Enrique, de Juana-Espinosa Susana and Valdés-Conca Jorge \\ Business Organization Department, Universidad de Alicante \\ Campus de San Vicente, Alicante, Spain
}

Correspondence should be addressed to: Valdés-Conca Jorge; Jorge.Valdes@ua.es

Received date: 21 October 2013; Accepted date: 23 January 2014; Published date: 10 July 2015

Academic Editor: Mohammad Mohammad

Copyright (C 2015. Claver-Cortes Enrique, de Juana-Espinosa Susana and Valdés-Conca Jorge. Distributed under Creative Commons CC-BY 4.0

\begin{abstract}
In the past decade, society and technology have made remarkable progress in the realm of the digital economy. Public administrations, in their double role as part and servant of society, must keep up with this progress, but this development does not happen without its difficulties. This paper aims to explore whether the transformation of local e-government environment has made a significant impact in the way municipalities face their challenges when implementing an e-government strategy. To do so, a longitudinal research was conducted to explore any changes within the perceived value of challenges to municipal egovernment initiatives over the past 8 years by local Chief Information Officers in Spain. This theoretical and empirical research contributes to the ongoing discussion on the varying role of technology as an explicit hindrance and as base for other challenges, and the impact of other non ICT-driven challenges for e-government. It also proposes a set of managerial implications to help overcoming said challenges based on the knowledge of local government experts in a contingent manner. The paper's results establish the significant and persistent effect of political interference in local e-government success in Spain, asserting that they are mostly non ICT-driven challenges that are viewed as significantly bigger obstacles today.
\end{abstract}

Keywords: Challenges, local government, public policy, public employees, difference of means, technology

\section{Introduction}

E-government has a myriad of definitions, because it is a multifaceted concept (Zhao et al., 2014) that refers to the many uses of Information and Communication Technology (ICT) to enhance public service delivery as well as to improve access to government information to all

Cite this Article as: Claver-Cortes Enrique, de Juana-Espinosa Susana and Valdés-Conca Jorge (2015)," Revisiting the Technological and Non-Technological Challenges to Municipal E-Government in Spain ", Journal of e-Government Studies and Best Practices, Vol. 2015 (2015), Article ID 2636968, 
stakeholders: citizens, businesses, politicians and other public entities (West, 2004). The ultimate goal of e-government is to improve the performance of public organizations. Nevertheless, there are a number of factors from different sources that are challenging public organizations in this journey towards efficiency and a better performance (Vassilakis et al., 2005; Rana et al., 2013).

Technology is one of these sources since it affects directly how public organizations manage their information to make better and faster decisions, as well as serving as support for the connection of citizens, public employees and political boards, helping them to become less bureaucratic and inefficient (Kamal and Alsudairi, 2009). ICT is also at the root of a number of challenges such as human capital, digital divide, privacy and security, etc. whereas there are other hindering aspects that have no relation to technology at all, such as organizational, legal and political issues (Rana et al., 2013). In fact, some authors consider technology a commodity (Carr, 2003), and argue that its role as pure source of challenges is decreasing in importance the minds of e-government practitioners despite its ubiquitousness and increasing sophistication (Helle and Ruckanova, 2011). It is crucial, therefore, to analyze the nature and effects of these challenges within their context so that the necessary decisions can be made.

For a better understanding of egovernment decision making practices, Yildiz (2007) calls for more processoriented studies (as opposed to outcomeoriented ones) seeking to analyze grounded primary data. Focusing on ICT policies effects on the public sector, Cordella and Bonina (2012) determine that most works are dedicated mostly to the managerial and economic aspects of ICT adoption and deployment, but not so much to their socio-political aspects. The aim of this paper is to fill in these research gaps with a double contribution: on the one hand, it discusses the evolution of ICT and non ICT-driven challenges based on both the literature and the knowledge of local government experts; and, on the other, it proposes a set of managerial implications to help understanding these challenges. To do so, a longitudinal quantitative survey was carried out in 2005 and again in 2013, in which the Chief Information Officers (CIO) of Spanish municipalities evaluate the main challenges to local e-government. These evaluations are statistically tested to see whether the important of said ICT and non ICT-driven challenges has significantly changed over time. Norris and Moon (2005), Carrizales et al. (2006) and Heeks and Bailur (2007) concur in appraising that longitudinal studies might offer a more holistic view in the research of the impact of Internet on public organizations; while Fidler et al. (2011) maintain that longitudinal approaches provide a richer understanding of e-government challenges.

The first part of this paper provides an upto-date review of the literature on the egovernment challenges faced by municipalities. The second section presents the research methodology after contextualizing the evolution of egovernment in Spain. The findings section discusses which challenges have experienced a significant change in their perceived effect upon local e-government within the considered period of time. The paper concludes with a number of recommendations to CIOs and policy makers in order to deal with these challenges.

\section{E-government challenges}

Rose (2000) attests to organizations having ICT-driven challenges since the emergence of Internet in the 1960's. Similarly, Bonham et al. (2001) and Norris et al. (2001) affirm that public administrations perceive the lack of technological infrastructures as a substantial challenge to the adequate provision of online public services and transactions. A basic challenge for egovernment lays on the public organizations' ability to develop, set up, operate and maintain an adequate infrastructure for an effortless and trustworthy access to e-government services, (Ebrahim and Irani, 2005; Vassilakis et al., 2005). Within this ability lies the access to funds to invest in secure 
and efficient technology (Ebrahim and Irani, 2005; Norris and Moon, 2005; Janssen et al., 2006). Nevertheless, Helle and Rukanova (2011) note that technology in a narrow sense is not perceived as a challenge for the most part of stakeholders, in spite of the rapid rate at which technology evolves.

The ability of stakeholders to be able to use ICT is similarly a traditional concern in egovernment literature (Norris et al., 2001; Li, 2003; Eyob, 2004). This challenge increases its effect with the degree of sophistication and complexity of the technological infrastructure (Norris and Moon, 2005; Fernando et al., 2012), which is directly related to the effectiveness of egovernment strategies (Layne and Lee, 2001). To avoid shortage of these skills, public administrations invest in staff training (Endicott, 2003, Weerakkody and Choudrie, 2005) or look at the private sector to recruit previously qualified personnel (Criado, 2012).

Following the same line of though, the political board is also a subject of study in regards to their ICT knowledge (ICMA, 2002; Eyob, 2004; EU, 2007). Reluctance to learn new ways to do things, especially when it involves the use of complex technology, is also found in politicians. This can be translated into disregard for egovernment initiatives; since they are not aware of the beneficial effects in the long term for the community they serve (Norris et al., 2001; Li, 2003; Ebrahim and Irani, 2005).

On the demand side for e-government services, the challenge of having a low demand for e-public services has been detected since the first surveys on the topic (ICMA, 2002; Vassilakis et al. 2005) and there is a growing recognition of the need for citizen training in its use (Criado, 2012) and to raise awareness of e-government initiatives (Weerakkody and Choudrie, 2005). However, demand-related challenges seem to be viewed as less common by the current literature (Rana et al., 2013). Still, the main challenge to overcome in this regard is the digital divide, either because of personal disabilities (Lazar and Jaeger, 2011), lack of convenient access to ICT infrastructures (Faisal and Rahman, 2008; Zhao et al., 2014), or digital illiteracy (EU, 2007; Ebbers et al, 2008; Faisal and Rahman, 2008).

Another reason for a low e-government demand is lack of citizen's trust (Rana et al., 2013). Ebrahim and Irani (2005) and Ebbers et al. (2008) emphasize that security and privacy of the electronic transactions is a considerable technological challenge. Hassan et al. (2011) affirm that this challenge is larger especially considering that the web 2.0 and social networks have been used for deceitful, jaundiced or injurious purposes towards the interests of public organizations.

As stated, not all challenges to egovernment have a technological component. For Sundberg and Sandberg (2006) the main challenge for egovernment is the tight power structures of bureaucratic organizations. In addition, reluctant employees will find it difficult to break from a traditional, orderly bureaucracy and assume the values of openness and flexibility of the digital society (Criado and Ramilo, 2003; Weerakkody and Choudrie, 2005; Riege and Lindsay, 2006; EU, 2007; Fernando et al. 2012). Citizens demand transparency and rapid responses to their online petitions, but their expectations collide with the giant machinery of bureaucracy. In many cases traditional work processes have been simply automatized, so that inefficiencies such as poor work coordination or organizational inflexibility have carried on (Eynon and Dutton, 2007).

Moreover, Helle and Rukanova (2011) point out that different national laws, local laws and stakeholders' contrary interests may complicate interoperation for the eprovision of public services. Criado and Ramilo (2003) and Vassilakis et al. (2005) bring up the necessity to have laws supporting the new environmental parameters of the digital economy. Because of this, Fidler et al. (2011) regards the question of legislation as a contingent challenge. 
And last, but not least, in accordance to Azjen's Theory of Planned Behavior (1991), e-government is being challenged by political interference, since the allocation of public resources mostly depends on their political significance. Therefore, the degree of leadership and commitment of the political board affects directly the availability of funding, human resources and infrastructure, or lack thereof (ICMA, 2002; Eyob, 2004). An insufficient budget is perceived as a severe challenge (Norris and Moon, 2005; EU, 2007) especially in the light of the last years' evolution of the general environment, which has changed notably from an expansion state in 2005 to that of the current recession, with subsequent restrictions in public expenditure and infrastructure. Faisal and Rahman (2008) go even further when they state that the lack of political willingness to adopt e-government initiatives is the primal cause for every other challenge encountered by the public sector in this quest.

\section{Methodology}

\section{The Research Context}

Spain is an excellent e-government study case because of its degree of public involvement in the new economy, so much that United Nations (UN) has awarded its public administration in several occasions (United Nations, 2014a). The country went from position $39^{\text {th }}$ of 193 in 2005 in UN's global e-government development index, with a score of 0.5874 (United Nations, $2005)$, to $12^{\text {th }}$ in 2014 with a markedly higher figure: 0.80410 (United Nations, 2014b). The latter actually shows a descent from the $9^{\text {th }}$ position achieved in 2010 (United Nations, 2010), possibly as a consequence of the public budget cuts imposed by the State Government in 2011 and 2012. Likewise, its online service index increased dramatically from 0.393 in 2005 (United Nations, 2005) to 0.9449 in 2014, despite the complexity of the Spanish governmental structure and its multiple administrations that often clash and fight for resources among them (MuñozCañavate and Hipola, 2010). Spanish local e-government has progressed in a similar manner, from a rare presence of e-service provision, barely 30\%, in 2005 (Fundación Orange, 2005) until 2013 when the average availability of high e-service provision in Spanish municipalities was over $80 \%$ (Fundación Orange, 2014).

The country's legislation supports this progression. Even though the Spanish Administrative Procedure and Legal System Act, still in force since 1992, presents a bureaucratic and political challenge without considering the benefits of an Internet-based provision of public services, political pressure has been put on e-government strategies since the National Government made it mandatory in 2007 that citizens may have online access to any public organization by 2010 (a.k.a. Act 11/2007) (Muñoz-Cañavate and Hipola, 2010).

In sum, legal and organizational aspects should be less of a concern for egovernment success in Spain, whereas the increasing sophistication of ICT and its enforced deployment by local councils may present a bigger challenge.

\section{Research design}

The present research results emanate from data collected in 2005 in 165 councils out of 960 that both had an official website and a population over 5000 inhabitants (response rate 17\%, SEM 7.78) and again in 2013 for 230 councils out of the same 960 (response rate 24\%, SEM 5.64\%). Both Layne and Lee (2001) and Baum and Maio (2000) established that the simplest stage of e-government is having a website. Although almost every city council over 5,000 inhabitants had at the time an e-mail address, only $75 \%$ of them had built their own official website. As for the second criterion, smaller municipalities may depend on higher level institutions for their IT decisions, plus their accordingly smaller budgets made it more difficult to invest in e-government strategies then (Hood, 1995; Pollitt, 2000). The latter part of the survey was carried out in two launches, one aimed to the councils that had answered in 2005 via email, and a second one surveying the rest of the universe, via postal mail to avoid the difficulties expressed by Endicott 
(2003). The reason for this two-step survey was to provide a strong and robust statistical significance to the final results.

Self coding questionnaires were distributed to the person in charge of the ICT department or, at least, of ICT issues within the local government. Zhang et al. (2005) point out the advantages in asking developer stakeholders, such as CIOs, for a knowledgeable assessment of the benefits and barriers of e-government. Responses were recorded on a five-point Likert scale anchored by 1 (none at all) to 5 (very strong).

To build the final list of challenges, only were selected those items which scored over 3 in a pilot test in 2005. This list consisted of five ICT-driven challenges and five non ICT-driven challenges. Content validity of a research instrument is provided when researchers concur that the items making it up cover the issues to be measured, thus representing a specific thematic universe. Our list of items can be considered as suitable since they have been obtained from a review of the literature and a qualitative test of the questionnaire among experts on the e-government field
(Elsheikh and Cullen, 2008, Zhang et al., 2005). Cronbach's analysis is used as an estimate of the reliability of a set of variables, evaluating its capacity to measure a single one-dimensional latent construct. For this survey, Cronbach's $\alpha$ was 0.8 in 2005, whereas in 2012, it measured 0.825 meaning that the items' internal consistency is good (Cronbach, 1951; Peterson, 1994).

Finally, in order to carry out the longitudinal analysis, a t-student test was used to see if there were any significant variations in the mean score of each challenge, which was complemented with a Levene's test for equality of variances.

\section{Findings and Discussion}

This section discusses the evolution of the most outstanding challenges for municipal e-government. Figure 1 shows the list of final items deemed as negative influences for local e-government strategies, according to their score in 2005 and 2013. The parameter "Mean" refers to the average degree of effect that such a factor has on e-government success, according to the CIOs' perceptions.

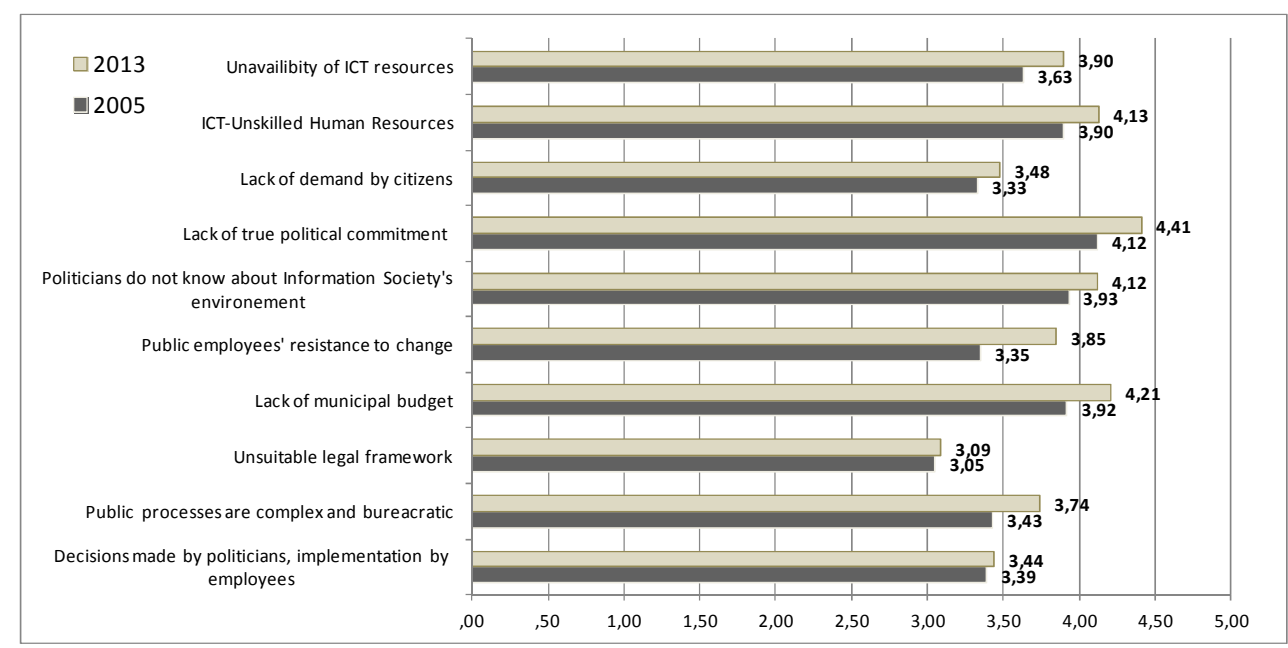

Source: own

Figure 1: E-government challenges in Spain 2005 and 2013

The evidence provided in Figure 1 can be interpreted as follows. First, it is indisputable that every single challenge considered in 2005 as important stayed that way in 2013 , with a score higher than 3 ; although the mean scores per challenge 
are not higher in all cases, as seen for Decision made by politicians and Unsuitable legal framework, whose scores are similar.

The biggest challenge for Spanish councils is the Lack of true political commitment, both in 2005 and 2013, which leads to understand that CIOs perceive that the most considerable challenges come from the political level, over those of technological or bureaucratic nature, as affirmed by Faisal and Rahman (2008). This finding is in line with the high score given to the fact that Politicians are ignorant of Information society's environment. Their lack of knowledge and awareness of the way society works does not seem to be conducive to fund egovernment initiatives, as shown by the consolidated second highest score of the Lack of municipal budget. This is a consequence of the double role of the politicians as project leaders and assigners of resources, like ICMA (2002) and Eyob (2004) determined.

The challenges that have increased their perceived value the most are Employees' resistance to change $(14.9 \%)$ and Public processes are complex and bureaucratic (9\%), which is expected since these two challenges are more apparent in times of implementation (Hassan et al., 2011). These items have one thing in common: the growing importance of the public organization's structure and workforce. CIOs recognize more clearly the danger of internal, bureaucratic challenges in 2013, when e-government initiatives are more advanced and implemented.

Finally, figure 1 also demonstrates that CIOs consistently perceive those challenges over which municipalities do not have full control, namely regulatory changes and customers' needs, are given the lowest scores.

Table 2: Evolution of challenges

\begin{tabular}{|c|c|c|c|c|c|c|c|c|c|c|c|c|}
\hline \multirow[b]{2}{*}{ Challenge } & \multicolumn{4}{|c|}{ Group statistics } & \multicolumn{8}{|c|}{ t-test for equality of means } \\
\hline & Year & Mean & Std. Dev. & $\begin{array}{l}\text { Std. Dev. } \\
\text { Mean }\end{array}$ & Levene's Test & $\mathbf{F}$ & Sig. & $\mathrm{t}$ & df & $\begin{array}{l}\text { Sig. (2- } \\
\text { tailed) }\end{array}$ & $\begin{array}{c}\text { Mean } \\
\text { Difference }\end{array}$ & $\begin{array}{l}\text { Std. Error } \\
\text { Difference }\end{array}$ \\
\hline \multirow{2}{*}{$\begin{array}{l}\text { Lack of true political } \\
\text { commitment }\end{array}$} & 2005 & 4,12 & 1,06289 & ,08377 & $\begin{array}{l}\text { Equal variances } \\
\text { assumed }\end{array}$ & 2,340 &, 127 & $-2,892$ & 388 & $0,004\left({ }^{* *}\right)$ &,- 29683 &, 10263 \\
\hline & 2013 & 4,41 & ,94958 & ,06275 & $\begin{array}{l}\text { Equal variances } \\
\text { not assumed }\end{array}$ & & & $-2,836$ & 319,376 & 005 &,- 29683 & , 10466 \\
\hline \multirow{2}{*}{$\begin{array}{c}\text { Politicians do not know about } \\
\text { Information Society's } \\
\text { environement }\end{array}$} & 2005 & 3,93 & 1,08139 & ,08523 & $\begin{array}{l}\text { Equal variances } \\
\text { assumed }\end{array}$ & ,930 & ,335 & $-1,844$ & 388 & $0,066\left(^{*}\right)$ &,- 19680 & ,10671 \\
\hline & 2013 & 4,12 & 1,00563 & ,06645 & $\begin{array}{l}\text { Equal variances } \\
\text { not assumed }\end{array}$ & & & $-1,821$ & 328,491 & ,070 &,- 19680 & , 10807 \\
\hline \multirow{2}{*}{ Lack of municipal budget } & 2005 & 3,92 & 1,04268 & ,08217 & $\begin{array}{l}\text { Equal variances } \\
\text { assumed }\end{array}$ & ,023 & 879 & 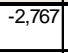 & 388 & $0,006\left({ }^{* *}\right)$ &,- 29035 & ,10493 \\
\hline & 2013 & 4,21 & 1,00424 & ,06636 & $\begin{array}{l}\text { Equal variances } \\
\text { not assumed }\end{array}$ & & & $-2,749$ & 336,354 & 006 &,- 29035 & ,10563 \\
\hline \multirow{2}{*}{$\begin{array}{l}\text { ICT-Unskilled Human } \\
\text { Resources }\end{array}$} & 2005 & 3,90 & ,963 & ,076 & $\begin{array}{l}\text { Equal variances } \\
\text { assumed }\end{array}$ & 2,497 & ,115 & $-2,280$ & 388 & $0,023\left(^{*}\right)$ &,- 230 & , 101 \\
\hline & \begin{tabular}{|l|}
2013 \\
\end{tabular} & 4,13 & ,996 & ,066 & $\begin{array}{l}\text { Equal variances } \\
\text { not assumed } \\
\end{array}$ & & & $-2,293$ & 351,531 & ,022 &,- 230 & , 100 \\
\hline \multirow{2}{*}{ Unavailibity of ICT resources } & 2005 & 3,63 & 1,04175 & ,08210 & $\begin{array}{l}\text { Equal variances } \\
\text { assumed }\end{array}$ & ,588 & ,444 & $-2,549$ & 388 & $0,011\left(^{*}\right)$ &,- 27223 & , 10679 \\
\hline & \begin{tabular}{|l|}
2013 \\
\end{tabular} & 3,90 & 1,03595 & ,06846 & $\begin{array}{l}\text { Equal variances } \\
\text { not assumed }\end{array}$ & & & $-2,547$ & 343,352 & ,011 &,- 27223 & , 10690 \\
\hline \multirow{2}{*}{$\begin{array}{l}\text { Public employees' resistance } \\
\text { to change }\end{array}$} & 2005 & 3,35 & 1,15331 & ,09089 & $\begin{array}{l}\text { Equal variances } \\
\text { assumed }\end{array}$ & , 170 & 680 & $-4,213$ & 388 & $0,00\left(^{* *}\right)$ &,- 49312 & ,11704 \\
\hline & 2013 & 3,85 & 1,12712 & ,07448 & $\begin{array}{l}\text { Equal variances } \\
\text { not assumed }\end{array}$ & & & $-4,196$ & 339,572 & ,000 &,- 49312 & ,11751 \\
\hline \multirow{2}{*}{$\begin{array}{l}\text { Public processes are complex } \\
\text { and bureacratic }\end{array}$} & 2005 & 3,42 & ,99775 & ,07863 & $\begin{array}{l}\text { Equal variances } \\
\text { assumed }\end{array}$ & ,522 & ,470 & $-3,114$ & 388 & $0,002\left({ }^{* *}\right)$ &,- 33310 & , 10695 \\
\hline & 2013 & 3,76 & 1,06850 & ,07061 & $\begin{array}{l}\text { Equal variances } \\
\text { not assumed }\end{array}$ & & & $-3,152$ & 358,486 & ,002 &,- 33310 & , 10568 \\
\hline \multirow{2}{*}{ Unsuitable legal framework } & 2005 & 3,05 & 1,07704 & ,08488 & $\begin{array}{l}\text { Equal variances } \\
\text { assumed }\end{array}$ & 2,598 & ,108 &,- 354 & 388 & ,724 &,- 04201 & ,11868 \\
\hline & \begin{tabular}{|l|l|}
2013 \\
\end{tabular} & 3,09 & 1,20502 & ,07963 & $\begin{array}{l}\text { Equal variances } \\
\text { not assumed }\end{array}$ & & &,- 361 & 366,399 &, 718 &,- 04201 & ,11639 \\
\hline \multirow{2}{*}{ Lack of demand by citizens } & 2005 & 3,33 & ,94059 & ,07413 & $\begin{array}{l}\text { Equal variances } \\
\text { assumed }\end{array}$ & 6,719 & $0,1\left(^{*}\right)$ & $-1,374$ & 388 & ,170 &,- 14679 & ,10684 \\
\hline & \begin{tabular}{|l|}
2013 \\
\end{tabular} & 3,48 & 1,10247 & ,07285 & $\begin{array}{l}\text { Equal variances } \\
\text { not assumed }\end{array}$ & & & $-1,412$ & 373,696 & ,159 &,- 14679 & ,10394 \\
\hline \multirow{2}{*}{$\begin{array}{l}\text { Decisions made by politicians, } \\
\text { implementation by employees }\end{array}$} & 2005 & 3,39 & 1,13012 & ,08907 & $\begin{array}{l}\text { Equal variances } \\
\text { assumed }\end{array}$ & 4,271 & $0,039\left(^{*}\right)$ &,- 343 & 388 & ,732 &,- 04538 & , 13216 \\
\hline & 2013 & 3,44 & 1,38338 & ,09142 & $\begin{array}{l}\text { Equal variances } \\
\text { not assumed }\end{array}$ & & & 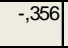 & 379,287 & ,722 &,- 04538 & 12763 \\
\hline
\end{tabular}

$\left({ }^{*}\right) p<0,1 \quad\left({ }^{* *}\right) p<0,01$

Source: own 
However, the mean score and the relative importance of each challenge is not enough to understand these differences may reflect a significant change in the minds of the local CIOs. To do that, we must look at the t-test results for difference of means in table 2. Indeed, there are three items for which the hypothesis of significant change must be rejected: Unsuitable legislation, Lack of demand by citizens and Decisions made by politicians, but implemented by employees. The first one is a consequence of the rapid advances that Spain has been making in this area with the legal changes introduced by Act 11/2007. For their part, citizens have a handful of ways to connect online with their municipality; but local administrations have met their expectations for e-government steadily, thus having supply and demand run in parallel, as seen in the contextualization section. Consequently, this is a challenge that is not viewed as significantly graver in 2013. As for the latter, the rupture in the decision making process is assumed as a cultural feature of the public sector and has not really been affected by the environmental transformation; therefore it makes sense that its perception as a challenge has not changed significantly since 2005. Public workers in Spain have very finely defined their limits and tasks, leaving most of the decision making to the political board.

The four challenges whose scores have most significantly changed are: Complexity of work processes and public bureaucracy, Public employees' resistance to change, Lack of true political commitment and Lack of municipal budget. These results reflect the greater effects of the political and economic crisis on the access to material and technical resources. Specifically, the Lack of true political commitment is particularly dangerous since if those in charge are not committed to this kind of project, any efforts in this direction will be fruitless in the end. If we add the monetary restrictions, which are shown to have significantly worsened within this recession period, local governments are fighting against a double-blade (tangiblemoney- and intangible - attitude-) sword.
In addition, the need for qualified human resources in local governments is growing significantly stronger in Spain since tenured civil servants are more reluctant to change because of the uncertainty and mistrust that transpires all over their organizations, coupled with the constricted hierarchies that conform the Spanish public sector (Muñoz-Cañavate and Hipola, 2010).

Finally, there are three challenges that reveal a significant evolution with a p-value smaller than 0,1: Politicians' lack of knowledge on e-government issues, Lack of skilled human resources and Unavailability of ICT resources. These three factors have in common that are ICT-driven and related to public service online provision and deployment of e-government initiatives. As it was stated before, the ignorance and lack of awareness of the political board makes it difficult to engage their commitment to local e-government projects. Also, the frustration of not being able to fully deploy ICT to overcome bureaucratic barriers and reduce administrative costs and time is more apparent now, when external and internal stakeholders are used to the presence of ICT in multiple aspects of their daily lives, as stated by Fernando et al. (2012).

In conclusion, although every challenge identified by the ICT experts is perceived at least as strong in 2013 than it was in 2005, not all of them have evolved in the same manner, nor have the same relative importance. There is not a specific pattern in the way the effect of these challenges is discerned, except for the fact that those items with lower scores are not significantly greater handicaps today for local e-government initiatives. Therefore, ICT, by itself and as a source of challenges, is not revealed as a sufficient condition for e-government success, although it does play a necessary role.

\section{Conclusions, Implications and Future Research}

This research verifies that the perceived impact of ICT-driven and non ICT-driven challenges to e-government has grown 
with time, but not in a consistent way. The t-student test establishes that not all of these differences can be considered significant, namely: Unsuitable legislation, Lack of demand by citizens and Decisions made by politicians, but implemented by employees, despite their higher scores in 2012. On the other hand, the Complexity of work processes and public bureaucracy, Public employees' resistance to change, Lack of true political commitment and Lack of municipal budget are persistently and significantly regarded as the main hindrances for municipal e-government success, their effects becoming more relevant with time.

These results show that the most critical challenges were and still are those related to political leadership and commitment, their perceived effect having significantly increased over the considered time gap. CIOs are more conscious of the negative effects of these challenges, particularly the scarcity of financial resources and the reluctance of public employees to change, which is not surprising considering the current economic and social circumstances of the Spanish public sector.

This study has a number of theoretical and practical implications; the major ones being the revealing of the challenges to egovernment success that are most salient to Spanish local councils, as well as depicting how CIOs' priorities and perceptions adjust to the transformed environment when facing these challenges. Municipalities and other public bodies should consider these challenges when designing their e-government strategies; and the longitudinal perspective of this research will provide support to decision makers when developing modernization processes, especially in view of the impact that ICT development has had on political, organizational and technical issues.

Although Fidler et al. (2011) assert that challenges to e-government implementation are largely countrydependent; we argue that lessons can be extracted for other countries to learn from if contextualized appropriately. In this line of thought, a number of lessons for policy makers and CIOs are proposed:

- As a consequence of the current recession and its effects, political and economic changes are perceived to affect the municipalities' strategies much more than the evolution of ICT. Thus, policy makers should concern themselves with the progress of the former while keeping an eye on the latter, so as not to become obsolete.

- $\quad$ Although ICT expenditure is still a strong challenge for local egovernment, this does not mean that local governments should not invest on ICT, but that their investment decisions should be aligned to their general strategy and level of maturity.

- Social networks and web 2.0 technologies have helped local CIOs identify and rise above bureaucratic challenges, by opening more flexible and cheaper communication channels by means of sharing information between internal (employees and politicians), and external stakeholders (citizens and businesses).

- $\quad$ The key to overcoming public employees' resistance to change is to work on their resilience, and to endow them with the resources deemed as necessary to be able to provide online public services in a satisfactory manner. This would also counteract the low demand for e-government, since citizens might be more attracted to use these services if the expected performance is positive.

Finally, this paper has a number of limitations. First, the survey focuses on one group of stakeholders, who are public employees with a high ICT proficiency level, and on medium-large municipalities. Other researchers might want to contemplate 
other stakeholders' perspectives, such as citizens, politicians or non ICT personnel, and other governments at different levels (Zhang et al. 2005); and by different countries around the world. Second, mediation and interaction variables are not considered, such as municipal budget variations or population growth. Regression and PLS models may help in clarifying these relationships. A third line of work would be to differentiate between limitations and challenges to adoption, implementation and diffusion of egovernment initiatives. Finally, this survey will benefit from international comparison. A prospective topic would be that of replicating the current research in other countries to see if similarities exist and to reveal common causes.

\section{Notes}

1

http://www.boe.es/diario_boe/txt.php?id= BOE-A-1992-26318

${ }^{2}$ http://www.seap.minhap.gob.es/dms/es/ publicaciones/centro_de_publicaciones_de_ la_sgt/Monografias/parrafo/01111111111 11111111114/text_es_files/Acceso-elecciudada-servic-pub.pdf

\section{References}

1. Ajzen, I. (1991) "The theory of planned behavior," Organizational Behavior and Human Decision Processes, 50 (2), 179-211.

2. Baum, C.H. and Di Maio, A. (2000), "Gartner's Four Phases of E-Government Model," [Online], [Retrieved June 6, 2013], http://www.gartner.com/DisplayDocumen t?id=317292.

3. Bonham, G., Seifert, J., and Thorson, S. (2001), "The transformational potential of e-government: the role of political leadership", Proceedings of the 4th Pan European International Relations Conference, Kent, UK.

4. Carrizales, T., Holzer, M., Kim, S.T. and Kim, C.G. (2006), "Digital governance worldwide: A longitudinal assessment of municipal web sites," International Journal of Electronic Government Research, 2(4), 123.

5. Carr, N. (2003), "IT doesn't matter", Harvard Business Review, May, 5-12.

6. Cordella, A. and Bonina, C. (2012), "A public value perspective for ICT enabled public sector reforms: a theoretical reflection", Government Information Quarterly, 29, 512-520.

7. Criado, J.I. and Ramilo, M.C. (2003), “EGovernment in practice. An analysis of website orientation to the citizens in Spanish municipalities," The International Journal of Public Sector Management, 126(3), 191-218.

8. Criado Grande, J.I. (2012), "Redes Sociales y Open Government," [Online], [Retrieved June 2, 2013], http://www.gobiernolocal.org/docs/public aciones/RDGL_18_19_baja.pdf

9. Cronbach, L.J. (1951), "Coefficient alpha and the internal structure of tests," Psychometrika, 16(3), 297-334.

10. Ebbers, W.E., Pieterson, W.J. and Noordman, H.N. (2008), "Electronic government: rethinking channel management strategies," Government Information Quarterly, 25(2), 181-201.

11. Ebrahim, Z. and Irani, Z. (2005), "EGovernment adoption: architecture and challenges," Business Process Management Journal, 11(5), 589-611.

12. Elsheikh, Y. and Cullen, A. (2008), "egovernment in Jordan: challenges and opportunities", Transforming Government: People, Process and Policy, 2(2), 83-103.

13. Endicott, R. (2003), "Researching local government using electronic surveys", Local Government Studies, 29 (2), 52-67.

14. European Union (2007), [Online], [Retrieved October 17, 2010], http://www.egovchallenges.org/download s/deliverables/solutions_report/Solutions_ for_eGovernment.pdf 
15. Eynon, R. and Dutton, W.H. (2007), "Barriers to networked governments: evidence form Europe”, Prometheus, 25(3), 225-242.

16. Eyob, E. (2004), "E-Government: breaking the frontiers of inefficiencies in the public sector," Electronic Government, 1(1), 107-114.

17. Faisal, N.S. \& Rahman, Z. (2008), “Egovernment in India: modelling the barriers to its adoption and diffusion", Electronic Government, 5(2), 181-202.

18. Fernando, S.; Choudrie, J., Lycett, $M$ and de Cesare, S. (2012), "Hidden assumptions and their influence in clinicians' acceptance of new IT systems in the NHS", Information Systems Frontiers, 14(2), 279-299.

19. Fidler, C.S.; Kanaan, R.K. and Rogerson, S. (2011), "Challenges to e-government implementation in Jordan: the role of Wasta", International Journal of Technology and Human Interaction, 7(2), 9-20.

20. Fundación Orange (2005), "Informe Anual sobre el Desarrollo de la Sociedad de la Información en España 2005," [Online], [Retrieved June 3, 2013], http://fundacionorange.es/areas/25_publi caciones/EESPA_A2005_COMPLETO_V3.pd $\mathrm{f}$

21. Fundación Orange (2014), "Informe Anual sobre el Desarrollo de la Sociedad de la Información en España 2014," [Online] [Retrieved June 13, 2014], http://www.proyectosfundacionorange.es /docs/eE2014/Informe_eE2014.pdf

22. Hassan, H.S., Shehab, E. and Peppard, J. (2011), "Recent advances in e-service in the public sector: state-of-the-art and future trends," Business Process Management Journal, 17 (3), 526-545.

23. Heeks, R. and Bailur, S. (2007), "Analyzing e-government research: Perspectives, philosophies, theories, methods, and practice," Government Information Quarterly, 24(2), 243-265.
24. Helle, Z.H. and Rukanova, B. (2011), "To mind or not to mind IT", Transforming Government: People, Process and Policy, 5(2), 155-166.

25. Hood, C. (1995), "The New Public Management in the 1980s: variations on a theme," Accounting Organisations and Society, 20(2/3), 93-109.

26. ICMA (2002), Digital government survey, Washington, DC.

27. Janssen, M., Gortmaker, J. and Wagenaar, R.W. (2006), "Web service orchestration in public administration: challenges, roles and growth stages," Information Systems Management, 23(2), 44-55.

28. Kamal, M.M. and Alsudairi, M. (2009), "Investigating the importance of factors influencing integration technologies adoption in local government authorities," Transforming Government: People, Process and Policy, 3(3), 302-331.

29. Layne, K., \& Lee, J. (2001), “Developing fully functional E-Government: A four stage model," Government Information Quarterly, 18(2), 122-136.

30. Lazar, J. \& Jaeger, P. (2001), "Reducing barriers to online access for people with disabilities", Issues in Science and Technology, 27(2), 69-82.

31. Li, F. (2003), "Implementing EGovernment strategy in Scotland: current situation and emerging issues," Journal of Electronic Commerce in Organizations, 1(2), 44-65.

32. Muñoz-Cañavate, A. and Hipola, P. (2011), "Electronic administration in Spain: From its beginnings to the present", Government Information Quarterly 28, 7480.

33. Norris, D.F., Fletcher, P.D. and Holden, S.H. (2001), "Is your local government plugged in? Highlights of the 2000 electronic government survey," Proceedings of the International City/County Management Association 
(ICMA) and Public Technology, Inc. (PTI), Maryland, MD.

34. Norris, D. F. \& Moon, M. J. (2005), "Advancing e-government at the grassroots: Tortoise or hare?" Public Administration Review, 65 (1), 64-75.

35. Peterson, R.A. (1994), "A Meta-analysis of Cronbach's Coefficient Alpha," Journal of Consumer Research, 21(2), 381-91.

36. Pollitt, C. (2000), "Is the emperor in his underwear? An analysis of the impacts of public management reform", Public Management, 2 (2), 181-199.

37. Rana, N.P.; Dwidevedi, Y.K. and Williams, M.D. (2013), "Analysing challenges, barriers and CSF of egov adoption", Transforming Government: People, Process and Policy, 7(2), 177-198.

38. Riege, A. and Lindsay, N. (2006), "Knowledge management in the public sector: stakeholder partnerships in the public policy development," Journal of Knowledge Management, 10(3), 24-39.

39. Rose, J. (2000), "The problem of technological barriers", Kibernetes, 29(5), 576-594.

40. Sundberg, H.K and Sandberg, K.W. (2006), "Towards e-government: a survey of problems in organizational processes," Business Process Management Journal, 21(2), 146-161.

41. United Nations (2005), "Global egovernment Readiness Report 2005," [Online], [Retrieved June 4, 2013], from http://unpan1.un.org/intradoc/groups/pu blic/documents/un/unpan021888.pdf

42. United Nations (2010), "United Nations e-government Survey 2010," [Online], [Retrieved November 25, 2011], http://unpan1.un.org/intradoc/groups/pu blic/documents/un/unpan038851.pdf.
43. United Nations (2014a), "Knowledge Base of UN Public Service Awards Initiatives" [Online], [Retrieved June 24], http://www.unpan.org/DPADM/UNPSDay Awards/KnowledgeBaseofUNPublicService Awards/tabid/1260/language/enUS/Default.aspx

44. United Nations (2014b), "United Nations e-government Survey 2014" [Online], [Retrieved June 24, 2014], http://unpan3.un.org/egovkb/Reports/UN -E-Government-Survey-2014

45. Vassilakis, C., Lepouras, G., Fraser, J., Haston, S. \& Georgiadis, P. (2005), "Challenges to electronic service development”, E-service Journal, 4(1), 4163.

46. Weerakkody, V. and Choudrie, J.(2005), "Exploring E-Government in the UK: Challenges, Issues and Complexities", Journal of Information Science and Technology, 2(2), 25-45.

47. West, D. (2004), "E-government and the transformation of service delivery and citizen attitudes", Public Administration Review, 61(1), 15-27.

48. Yildiz, M. (2007), "E-Government Research: Reviewing the Literature, Limitations, and Ways Forward", Government Information Quarterly, 24, 646665.

49. Zhang, J., Dawes, S.S., and Sarkis, J. (2005), 'Exploring stakeholders' expectations of the benefits and barriers of e-government knowledge sharing", Journal of Enterprise Information Management, 18(5), 548-567.

50. Zhao, F.; Collier, A. and Deng, H. (2014), "A multidimensional and integrative approach to study global digital divide and e-government development", Information Technology \& People, 27 (1), 38 - 62 